\title{
Penerapan Metode Random Over-Under Sampling dan Random Forest untuk Klasifikasi Penilaian Kredit
}

\author{
Akhmad Syukron $^{1}$, Agus Subekti ${ }^{2}$ \\ ${ }^{1}$ AMIK BSI Yogyakarta \\ e-mail: akhmad.khy@bsi.ac.id \\ ${ }^{2}$ Lembaga IImu Pengetahuan Indonesia (LIPI) \\ e-mail: agus.subekti@lipi.go.id
}

\begin{abstract}
Abstrak
Penilaian kredit telah menjadi salah satu cara utama bagi sebuah lembaga keuangan untuk menilai resiko kredit, meningkatkan arus kas, mengurangi kemungkinan resiko dan membuat keputusan manajerial. Salah satu permasalahan yang dihadapai pada penilaian kredit yaitu adanya ketidakseimbangan distribusi dataset. Metode untuk mengatasi ketidakseimbangan kelas yaitu dengan metode resampling, seperti menggunakan Oversampling, undersampling dan hibrida yaitu dengan menggabungkan kedua pendekatan sampling. Metode yang diusulkan pada penelitian ini adalah penerapan metode Random OverUnder Sampling Random Forest untuk meningkatkan kinerja akurasi klasifikasi penilaian kredit pada dataset German Credit. Hasil pengujian menunjukan bahwa klasifikasi tanpa melalui proses resampling menghasilkan kinerja akurasi rata-rata $70 \%$ pada semua classifier. Metode Random Forest memiliki nilai akurasi yang lebih baik dibandingkan dengan beberapa metode lainnya dengan nilai akurasi sebesar 0,76 atau $76 \%$. Sedangkan klasifikasi dengan penerapan metode Random Over-under sampling Random Forest dapat meningkatkan kinerja akurasi sebesar $14,1 \%$ dengan nilai akurasi sebesar 0,901 atau 90,1\%. Hasil penelitian menunjukan bahwa penerapan resampling dengan metode Random Over-Under Sampling pada algoritma Random Forest dapat meningkatkan kinerja akurasi secara efektif pada klasifikasi tidak seimbang untuk penilaian kredit pada dataset German Credit.
\end{abstract}

Kata kunci: Penilaian Kredit, Random Forest, Klasifikasi, ketidakseimbangan kelas, Random Over-Under Sampling

\section{Abstract}

Credit scoring has become one of the main ways for a financial institution to assess credit risk, improve cash flow, reduce the possibility of risk and make managerial decisions. One of the problems faced by credit scoring is the imbalance in the distribution of datasets. The method to overcome class imbalances is the resampling method, such as using Oversampling, undersampling and hybrids by combining both sampling approaches. The method proposed in this study is the application of the Random Over-Under Sampling Random Forest method to improve the accuracy of the credit scoring classification performance on German Credit dataset. The test results show that the classification without going through the resampling process results in an average accuracy performance of $70 \%$ for all classifiers. The Random Forest method has a better accuracy value compared to some other methods with an accuracy value of 0.76 or $76 \%$. While classification by applying the Random Over-under sampling + Random Forest method can improve accuracy performance $14.1 \%$ with an accuracy value of 0.901 or 90.1\%. The results showed that the application of resampling using Random Over-Under Sampling method in the Random Forest algorithm can improve accuracy performance effectively on an unbalanced classification for credit scoring on German Credit dataset.

Keywords: Imbalance Class, Credit Scoring, Random Forest, Classification, Resampling 


\section{Pendahuluan}

Penilaian kredit telah menjadi salah satu cara utama bagi sebuah lembaga keuangan untuk menilai resiko kredit, meningkatkan arus kas, mengurangi kemungkinan resiko dan membuat keputusan manajerial (Lin, Wang, Xie, \& Zhong, 2017). Penilaian kredit juga sebagai proses pengakuan pelanggan bank untuk memberikan kredit berdasarkan seperangkat kriteria tententu (Koutanaei, Sajedi, \& Khanbabaei, 2015). Tujuan dari penilaian kredit adalah untuk mengklasifikasi para calon pemohon kredit yang diklasifikasikan menjadi dua jenis yaitu calon pemohon yang baik dan calon pemohon yang buruk. Penilaian kredit tersebut berdasarkan dari kemampuan calon pemohon untuk membayar kewajiban keuangannya dengan melihat karakteristik seperti jenis kelamin, umur, pekerjaan, dan gaji dan lain sebagainya (He, Zhang, \& Zhang, 2018).

Ada dua teknik klasifikasi utama yang digunakan untuk penilaian kredit, yaitu dengan teknik statistik dan machine learning $(\mathrm{He}, 2018)$. Beberapa teknik statistik yang telah banyak digunakan dalam penilaian kredit yaitu seperti Linear Discriminant Analysis (LDA), Logistic Regression Analysis (LRA) (Zhang, Yang, \& Zhou, 2018). Selain itu penggunaan teknik machine learning dengan menggunakan Artificial Intelegen (Al) seperti Artificial Neural Networks (ANN), Decision tree (DT), Case-Based Reasoning (CBR), Support Vector Machine (SVM) dan lainnya telah banyak digunakan diberbagai penelitian tentang penilaian kredit (Wang, Hao, Ma, \& Jiang, 2011).

Salah satu permasalahan yang dihadapi dalam penggunaan teknik machine learning yaitu masalah ketidakseimbangan kelas. Ketidak- seimbangan kelas terjadi pada saat kelas minoritas jauh lebih kecil atau lebih jarang dari kelas mayoritas (Ren, Cao, Li, Zhao, \& Zaiane, 2017). Model yang dibuat dengan menggunakan data tidak seimbang akan menghasilkan akurasi prediksi minoritas yang rendah. Informasi yang kaya dari kelas mayoritas mendominasi kelas minoritas sehingga menyebabkan batas-batas keputusan yang bias dalam sistem klasifikasi (Jian, Gao, \& Ao, 2016).

Beberapa metode untuk mengatasi ketidakseimbangan kelas dapat dibagi menjadi tiga kategori. Pertama yaitu dengan teknik tingkat data yang berusaha menyeimbangkan distribusi data dengan metode over-sampling dan undersampling. Kedua adalah pendekatan tingkat algoritma yaitu dengan mengembangkan algoritma baru atau memodifikasi metode yang ada untuk memperhitungkan arti dari kelas minor. Ketiga dengan mengkombinasikan pendekatan algoritma dan pendekatan level data (Xiao, Xie, He, \& Jiang, 2012).

Untuk mengatasi masalah ketidakseimbangan kelas, maka pada penelitian ini menggunakan pendekatan level data dengan menerapkan metode resampling, yaitu Random over-under sampling pada algoritma random forest. Sehingga dapat meningkatkan kinerja akurasi pada klasifikasi penilaian kredit.

Thomas dalam Koutanaei mendefinisikan penelianan kredit sebagai proses pengakuan pelanggan bank untuk memberikan kredit berdasarkan seperangkat kriteria tententu. Secara umum penilaian kredit memiliki beberapa keunggulan yaitu;

1. mengurangi biaya analisis kredit.

2. Penetapan kredit dengan proses pengambilan keputusan yang efektif dan cepat.

3. Probabilitas pembayaran kredit yang lebih tinggi.

4.kemungkinan resiko lebih rendah (Koutanaei et al., 2015).

Tujuan dari penilaian kredit adalah untuk mengklasifikasi para calon debitur yang diklasifikasikan menjadi dua jenis yaitu calon debitur yang baik dan calon debitur yang buruk. Penilaian kredit tersebut berdasarkan dari kemampuan calon debitur untuk membayar kewajiban keuangannya. Calon debitur dengan penilaian kredit yang bagus memiliki kemungkinan besar untuk membayar kewajiban keuangan. Sedangkan calon debitur dengan penilaian kredit yang buruk memiliki kemungkinan gagal untuk membayar kewajiban keuangan. Keakuratan pemberian niai kredit sangatlah penting untuk profitabilitas lembaga keuangan. Dengan adanya peningkatan akurasi penilaian kredit terhadap calon debitur dengan resiko macet maka dapat menurunkan kerugian bagi lembaga keuangan (Wang et al., 2011).

Klasifikasi adalah proses penemuan model (fungsi) yang menggambarkan dan membedakan kelas data atau konsep yang bertujuan agar bisa digunakan untuk memprediksi kelas dari objek yang label kelasnya tidak diketahui. Klasifikasi telah banyak digunakan seperti pada deteksi 
penipuan, target pemasaran, prediksi kinerja, manufaktur, dan diagnosis medis (Han,2012). Proses klasifikasi data terdiri dari 2 langkah. Pertama yaitu tahap learning (fase training), dimana algoritma klasifikasi dibuat untuk menganalisa data training lalu direpresentasikan dalam bentuk model klasifikasi. Proses kedua adalah tahap klasifikasi, dimana data tes digunakan untuk memperkirakan akurasi dari model klasifikasi. Jika akurasi dianggap dapat diterima, aturan bisa diterapkan pada klasifikasi tupel data baru (Han,2012).

Class imbalance atau ketidakseimbangan kelas merupakan salah satu permasalahan yang ada pada data minning. Hal ini terjadi pada saat kelas minoritas jauh lebih kecil atau lebih jarang dari kelas mayoritas (Ren et al., 2017). Model yang dibuat dengan menggunakan data tidak simbang akan menghasilkan akurasi prediksi minoritas yang rendah. Informasi yang kaya dari mayoritas mendominasi minoritas sehingga menyebabkan batas-batas keputusan yang bias dalam sistem klasifikasi (Jian et al., 2016). Selain itu ketidakseimbangan kelas (class imbalance) dan noise juga dapat berpengaruh pada kualitas data dalam hal kinerja klasifikasi.

Teknik resampling adalah salah satu teknik preprocessing dimana distribusi data diseimbangkan kembali untuk mengurangi efek distribusi kelas tidak seimbang dalam proses pembelajaran (Jian et al., 2016).

- Teknik resampling secara luas digunakan untuk memecahkan masalah data yang tidak seimbang. Teknik ini dilakukan dengan mencoba menyeimbangkan data asli berdasarkan serangkaian algoritma sampling dengan menyesuaikan jumlah sampel dalam kelas yang berbeda, kemudian melatih data "seimbang" baru dengan mengadopsi algoritma klasifikasi.

Pendekatan resampling dibagi menjadi tiga kategori: metode over-sampling, undersampling, dan hibrida yang menggabungkan kedua pendekatan sampling (Jian et al., 2016). Salah satu teknik resampling yang umum digunakan yaitu undersampling yang secara acak memilih sampel di kelas mayoritas dan menambahkannya ke kelas minoritas, membentuk sebuah dataset pelatihan baru. Oversampling bertujuan untuk meningkatkan sampel kelas minoritas sampai sama dengan kelas mayoritas lain dengan menduplikasi secara acak sampel kelas minoritas (He et al., 2018). Sedangkan random undersampling yaitu menghasilkan subsampel acak dari instance kelas mayoritas (Rajesh \& Dhuli, 2018). Undersumpling : metode sampling ini secara acak memilih sampel di kelas mayoritas dan menambahkannya ke kelas minoritas, membentuk sebuah dataset pelatihan baru (He et al., 2018).

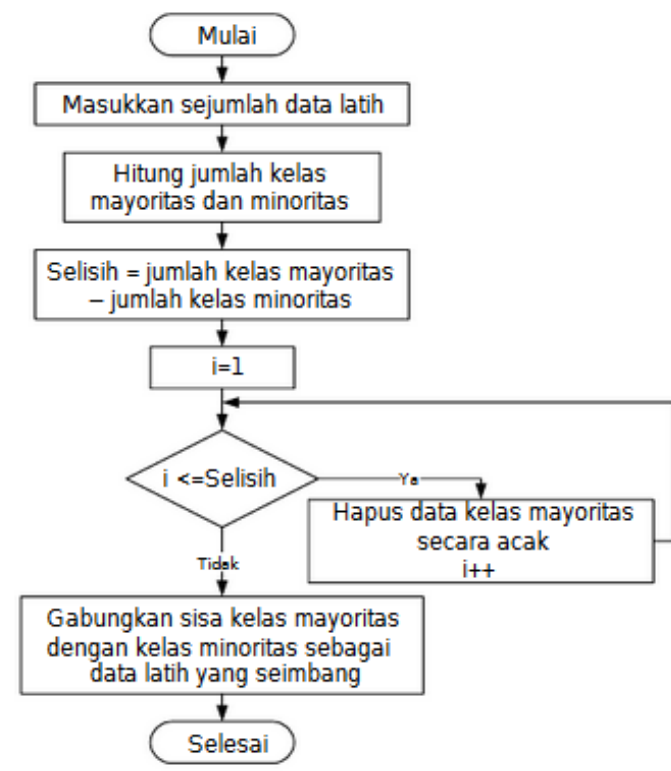

Gambar 1. Flowcart Algoritma RandomUndersampling

Sumber : (Saifudin et al., 2015)

Oversampling : Dalam metode ini, contoh dari kelas minoritas dipilih secara acak dan diduplikasi. instance yang dihasilkan hanya meningkatkan besarnya jumlah kelas minoritas dengan hanya mereplikasi informasi yang sama[1]. Salah satu teknik overampling yang populer dalam menangani ketidakseimbangan kelas yaitu SMOTE (Synthetic Minority Over-sampling Technique). 


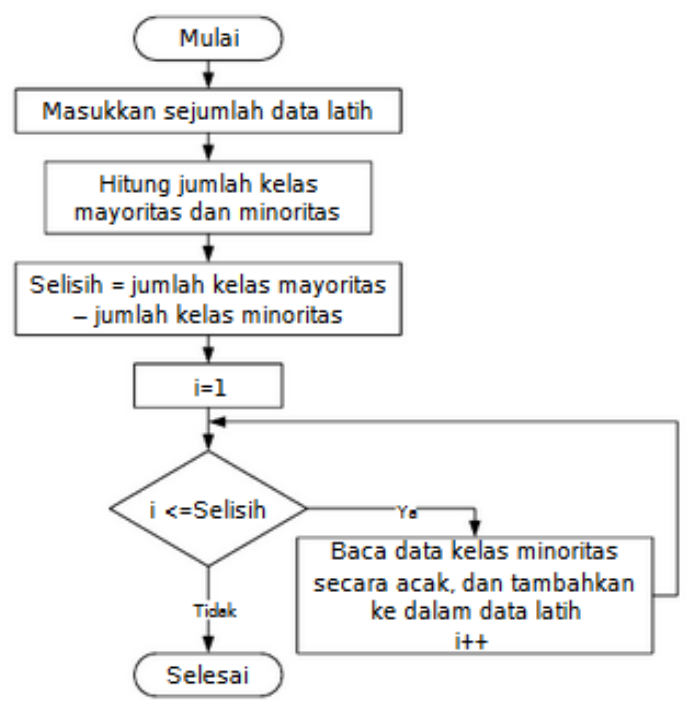

Gambar 2. Flowcart Algoritma

RandomOversampling

Sumber : (Saifudin et al., 2015)

Random forest adalah metode ensemble learning yang pertama kali diusulkan oleh Breiman pada tahun 2001 yang merupakan kombinasi dari pohon klasifikasi sedemikian

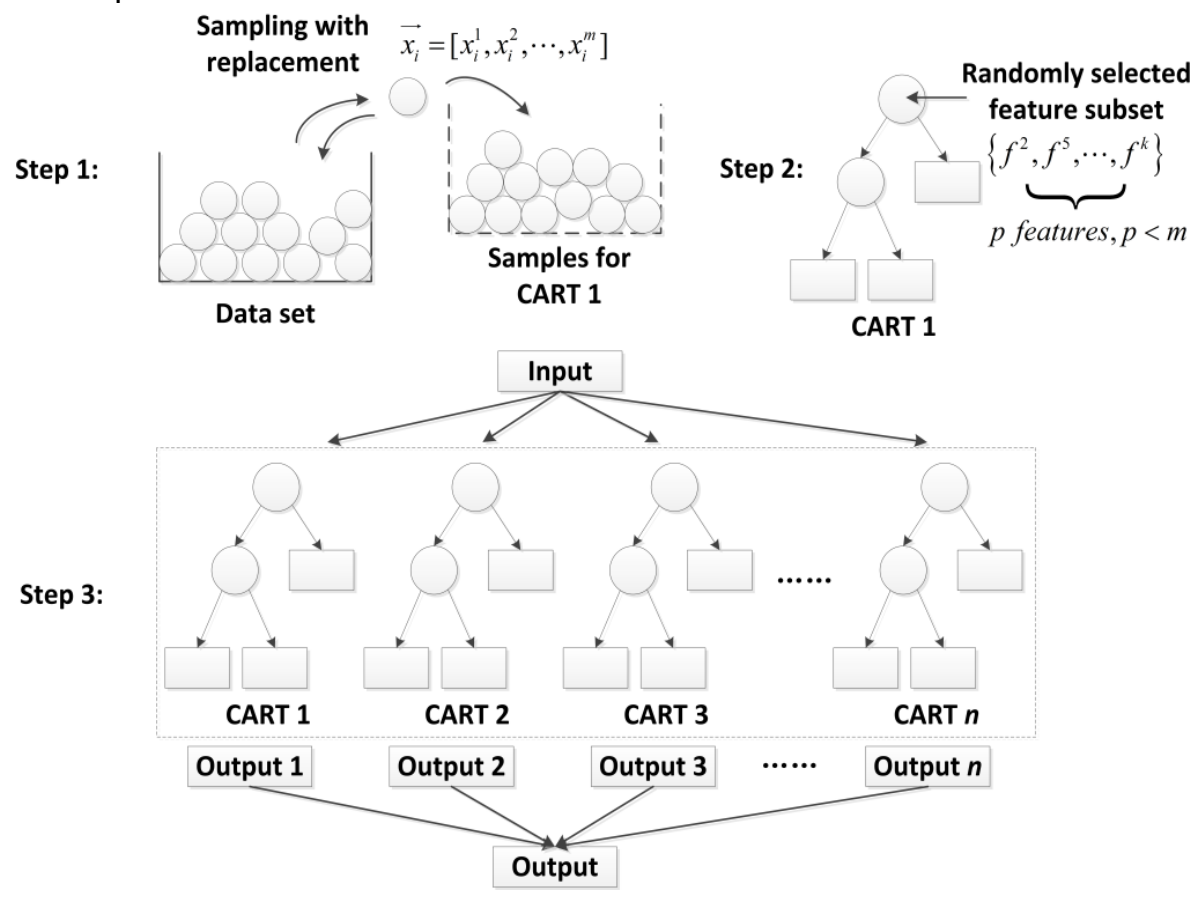

Gambar 3. Flowcart Algoritma Random Forest

Sumber : (Lin et al., 2017)

Pada Penelitian Lean Yu,dkk mengusulkan penerapan deep belief network (DBN) berbasis resampling support vector machine (SVM) ensemble learning untuk memecahkan masalah data tidak seimbang rupa sehingga setiap pohon bergantung pada nilai acak vektor sampel secara mandiri dan dengan distribusi yang sama untuk semua pohon di hutan (Xiao et al., 2012).

Random Forest telah banyak digunakan baik untuk klasifikasi dan regresi karena kinerjanya yang unggul dan strukturnya yang sederhana (Lin et al., 2017).

Langkah-langkah rinci dari Random Forest adalah sebagai berikut.

1. Menghasilkan Sebuah set-set pelatihan baru dengan sampel acak dengan penggantian (bootstrap) dari set pelatihan asli.

2. Untuk setiap set pelatihan baru, dibangun sebuah pohon dengan pemilihan fitur acak di setiap simpul pohon dan tanpa pemangkasan.

3. Setelah sejumlah besar pohon dihasilkan, data baru diprediksi dengan menggabungkan hasil semua pohon, dengan strategi voting mayoritas. 
network (DBN) berbasis ensemble terintegrasi dengan teknik re-sampling, terutama pada masalah ketidakseimbangan data.

Penelitian Jie Sun, dkk ini mengusulkan penerapan model ensemble Decision Tree (DTE) yang efektif dengan menggabungkan SMOTE (Sinthetic Minority over-sampling technique) dan Bagging dengan DSR (Differentiated sampling rates), yang disingkat sebagai DTE-SBD, sehingga dapat meningkatkan kinerja ketidakseimbangan class pada evaluasi kredit perusahaan dengan membandingkan enam model yaitu Decission Tree murni, Decission Tree oversampling, Decission Tree over-undersampling, SMOTE Decission Tree, Bagging Decission Tree, dan DTE-SBD.

Penelitian (Yun Qian, dkk mengusulkan penerapan model Resampling Ensemble algorithm (REA) dengan Naïve Bayes sebagai base learning method dan ensemble learning menggunakan Bagging yang berfokus pada masalah klasifikasi pada dataset yang tidak seimbang. Pada metode ini, kelas-kelas dengan data yang kecil dioversampling dan kelas-kelas dengan data yang besar di undersampling dan resampling skala ditentukan berdasarkan rasio jumlah kelas minimal dan jumlah kelas maksimal. Hasil penelitian dari permasalahan multiple class menunjukkan bahwa ensemble dari berbagai jenis metode dapat meningkatkan kinerja algoritma secara efisien

\section{Metode Penelitian}

Pada penelitian ini jenis penelitian yang dilakukan adalah jenis Eksperimen komparatif akan membandingkan dua objek yang berbeda, misalnya membandingkan dua algoritma yang berbeda dengan melihat hasil statistik masing-masing mana yang lebih baik. Dimana Melibatkan penyelidikan hubungan kausal menggunakan tes yang dikontrol sendiri (Dawson,2009).

Penelitian ini bertujuan untuk melakukan komparasi dan evaluasi model ensemble menggunakan random forest dan metode resampling untuk mengetahui algoritma yang memiliki nilai akurasi lebih tinggi pada klasifikasi tidak seimbang penilain kredit. Data yang digunakan dalam penelitian ini adalah data sekunder yang didapat dari UCl (University of California, Irvine) Machine Learning Repository.

Metode pengumpulan data yang dilakukan pada penelitian ini adalah menggunakan data sekunder yang diperoleh dari University of California Irvine machine learning data repository yang dapat diperoleh melalui alamat web https://archive.ics.uci.edu/ml/datasets/statlog +(german+credit+data).

Pada penelitian ini model yang diusulkan untuk mengatasi masalah ketidakseimbangan kelas yaitu dengan menerapkan kombinasi teknik pendekatan level data dengan metode resampling dan menggunakan pendekatan algoritma dengan metode ensemble berbasis random forest. Kerangka model yang diusulkan ditunjukan pada gambar 3.1.

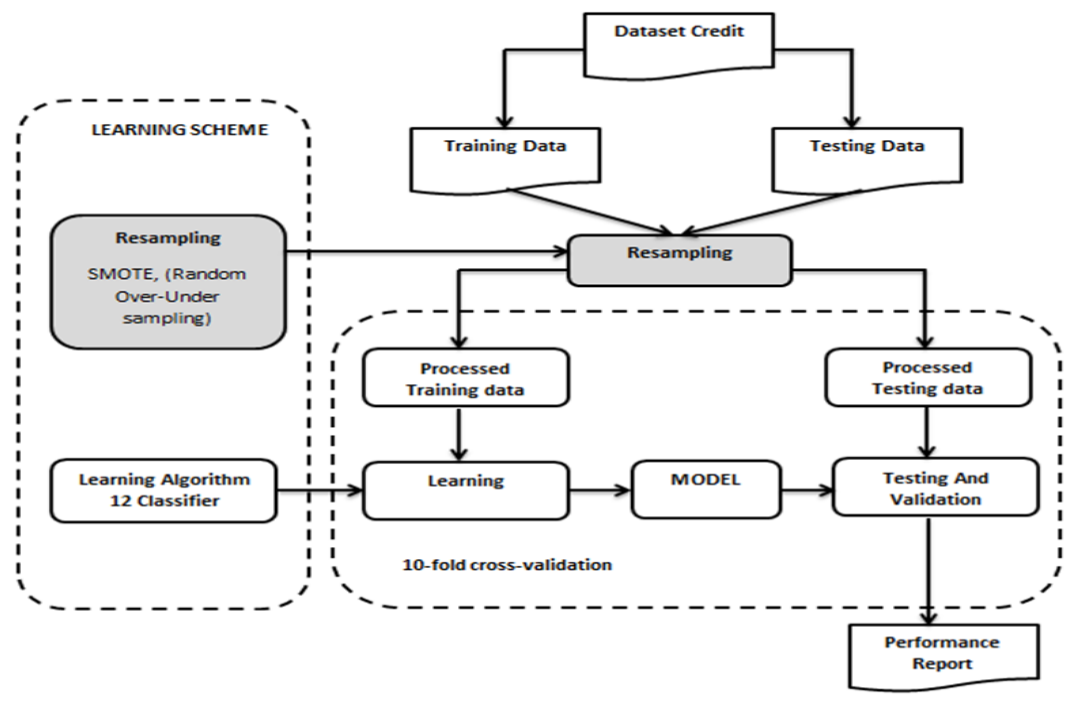

Gambar 4. Metode Usulan

Sumber : Penelitian (2018) 
Pada metode yang diusulkan, tahapan awal akan dilakukan yaitu menerapkan metode resampling seperti SMOTE, dan Random Over-Under Sampling (ROUS) pada dataset German Credit agar dataset menjadi lebih seimbang. Tahapan berikutnya dilakukan pemodelan pada data training dengan menggunakan metode Random Forest dan 11 model algoritma klasifikasi lainnnya sebagai pembanding dan diuji dengan data uji melalui proses validasi. Hasil validasi digunakan untuk mengukur kinerja masingmasing model. Komparasi dilakukan dengan membandingkan kinerja Random Forest dengan 11 model algoritma dengan metode resampling seperti SMOTE, Random OverUnder Sampling dan juga tanpa melalui proses resampling. Untuk mengukur kinerja algoritma pengklasifikasi dilakukan dengan menggunakan confusion matrix yang diperoleh dari proses validasi menggunakan $\mathrm{k}$-fold croos validation dengan metode evaluasi standarnya yaitu 10-fold cross validation yang merupakan pilihan terbaik untuk mendapatkan hasil validasi yang akurat. Hasil yang diperoleh dari pengukuran kinerja model digunakan untuk dibandingkan antara algoritma random forest dengan beberapa model algoritma lainnya. Baik model yang dibentuk dengan kombinasi metode resampling maupun tanpa metode resampling. Kualitas model dapat dilihat berdasarkan niai Accuracy, F-measure dan juga nilai Area Under curve (AUC).

3.

\section{Hasil Dan Pembahasan}

Pada bab ini membahas hasil eksperimen yang telah dilakukan dengan menggunakan aplikasi WEKA 3.8.1. Dataset yang digunakan pada penelitian ini adalah dataset German Credit yang terdiri dari 20 atribut, 1000 instance dan 2 class yaitu class "good" dan class "bad". Dengan jumlah instance masing-masing class yaitu 700 untuk class "good", dan 300 instance untuk class "bad". Pengaturan eksperimen dilakukan untuk menghasilkan akurasi yang paling tinggi pada metode yang diusulkan yaitu dengan membandingkan metode random forest dengan beberapa metode lainnya dengan penerapan resampling seperti SMOTE dan Random Over-Under Sampling ataupun tanpa resampling.

\subsection{Klasifikasi Random Forest}

Pada tahapan ini experimen dilakukan tanpa menggunakan metode resampling. Tetapi Langsung dilakukan pemodelan dan pengujian menggunakan metode random forest. Hasil pengujian dibandingkan dengan 11 metode lainnya untuk menghasilkan model dengan kinerja akurasi terbaik. Hasil pengujian model pengklasifikasi tanpa resampling disajikan pada tabel 1 .

Tabel 1. Perbandingan kinerja model Pengklasifikasi Tanpa Resampling

\begin{tabular}{|c|l|l|l|l|l|l|l|l|}
\hline No & Algoritma & TPRate & FPRate & $\begin{array}{c}\text { Preci- } \\
\text { ssion }\end{array}$ & Recall & Accuracy & F-Measure & AUC \\
\hline 1 & J48 & 0,843 & 0,610 & 0,763 & 0,843 & 0,707 & 0,801 & 0,617 \\
\hline 2 & Naïve Bayes & 0,864 & 0,503 & 0,800 & 0,864 & 0,754 & 0,831 & 0,681 \\
\hline 3 & KNN & 0,891 & 0,607 & 0,774 & 0,891 & 0,742 & 0,829 & 0,642 \\
\hline 4 & SMO & 0,873 & 0,530 & 0,794 & 0,873 & 0,752 & 0,831 & 0,672 \\
\hline 5 & Multi Layer Perceptron & 0,809 & 0,477 & 0,798 & 0,809 & 0,723 & 0,803 & 0,666 \\
\hline 6 & Random Forest & 0,913 & 0,597 & 0,781 & 0,913 & 0,760 & 0,842 & 0,658 \\
\hline 7 & Adaboost + J48 & 0,803 & 0,517 & 0,784 & 0,803 & 0,707 & 0,793 & 0,643 \\
\hline 8 & Adaboost + Naïve & 0,860 & 0,493 & 0,803 & 0,860 & 0,754 & 0,830 & 0,684 \\
\hline 9 & Adayes & 0,870 & 0,540 & 0,790 & 0,870 & 0,747 & 0,828 & 0,665 \\
\hline 10 & Bagging + J48 & 0,863 & 0,570 & 0,779 & 0,863 & 0,733 & 0,819 & 0,647 \\
\hline 11 & Bagging + Naïve Bayes & 0,859 & 0,510 & 0,797 & 0,859 & 0,748 & 0,827 & 0,675 \\
\hline 12 & Bagging + SMO & 0,876 & 0,530 & 0,794 & 0,876 & 0,754 & 0,833 & 0,673 \\
\hline
\end{tabular}


Pada tabel 1 menunjukkan bahwa model Random forest memiliki nilai accuracy dan F-Measure yang lebih baik daibandingkan dengan beberapa model lainnya dengan nilai accuracy sebesar 0,76 dan nilai $F$-Measure sebesar 0,842 . Grafik perbandingan kinerja 12 model pengklasifikasi disajikan pada gambar 5 .

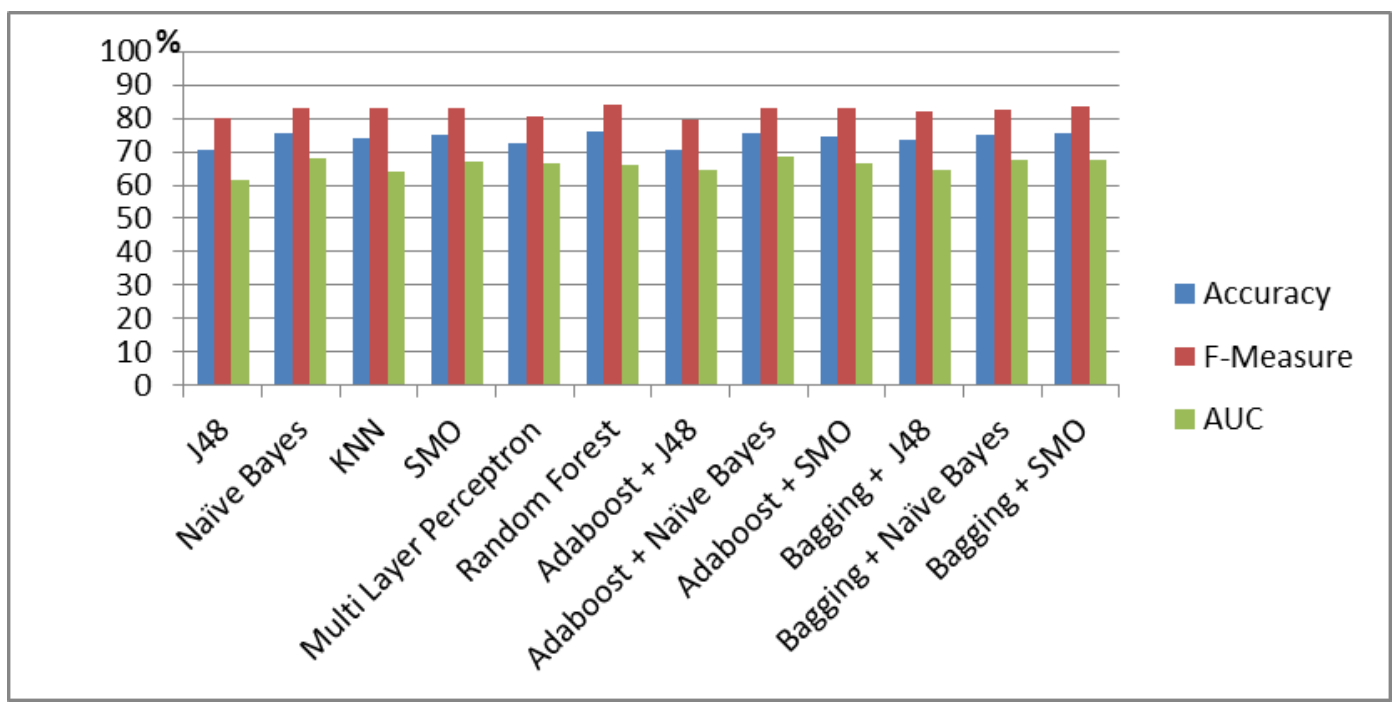

Gambar 5. Perbandingan kinerja pemodelan tanpa Resampling

3.2. Klasifikasi SMOTE Random Forest

Experimen dilakukan dengan menerapkan SMOTE (Synthetic Minority Over-sampling Technique) pada metode random forest. Dimana data training menjadi lebih seimbang antara kelas "good" dengan kelas "bad" dengan jumlah instance pada class "good"
700 instance, sedangkan class "bad" menjadi 600 instance. Hasil pengujian dibandingkan dengan 11 metode lainnya untuk menghasilkan model dengan kinerja accuracy terbaik. Hasil pengujian model pengklasifikasi dengan SMOTE disajikan pada tabel 2.

Tabel 2. Perbandingan kinerja model Pengklasifikasi dengan metode Resampling SMOTE(Synthetic Minority Over-sampling Technique)

\begin{tabular}{|c|l|c|c|c|c|c|c|c|}
\hline No & \multicolumn{1}{|c|}{ Algoritma } & $\begin{array}{c}\text { TP- } \\
\text { rate }\end{array}$ & $\begin{array}{c}\text { FP- } \\
\text { rate }\end{array}$ & $\begin{array}{c}\text { Preci- } \\
\text { ssion }\end{array}$ & Recall & $\begin{array}{c}\text { Accu- } \\
\text { racy }\end{array}$ & $\begin{array}{c}\text { F- } \\
\text { Measure }\end{array}$ & AUC \\
\hline 1 & SMOTE+J48 & 0,786 & 0,290 & 0,760 & 0,786 & 0,751 & 0,772 & 0,748 \\
\hline 2 & SMOTE+Naïve Bayes & 0,801 & 0,235 & 0,799 & 0,801 & 0,785 & 0,800 & 0,783 \\
\hline 3 & SMOTE+KNN & 0,706 & 0,180 & 0,821 & 0,706 & 0,758 & 0,759 & 0,763 \\
\hline 4 & SMOTE+SMO & 0,786 & 0,212 & 0,812 & 0,786 & 0,787 & 0,799 & 0,787 \\
\hline 5 & $\begin{array}{l}\text { SMOTE+Multilayer } \\
\text { perseptron }\end{array}$ & 0,784 & 0,268 & 0,773 & 0,784 & 0,760 & 0,779 & 0,758 \\
\hline $\mathbf{6}$ & $\begin{array}{l}\text { SMOTE+Random } \\
\text { Forest }\end{array}$ & 0,833 & 0,220 & 0,815 & 0,833 & 0,808 & 0,824 & 0,807 \\
\hline 7 & $\begin{array}{l}\text { SMOTE+(Adaboost + } \\
\text { J48) }\end{array}$ & 0,781 & 0,260 & 0,778 & 0,781 & 0,762 & 0,780 & 0,761 \\
\hline 8 & $\begin{array}{l}\text { SMOTE+(Adaboost + } \\
\text { Naïve Bayes) }\end{array}$ & 0,797 & 0,233 & 0,799 & 0,797 & 0,783 & 0,798 & 0,782 \\
\hline 9 & $\begin{array}{l}\text { SMOTE+(Adaboost + } \\
\text { SMO) }\end{array}$ & 0,786 & 0,212 & 0,812 & 0,786 & 0,787 & 0,799 & 0,787 \\
\hline
\end{tabular}




\begin{tabular}{|c|l|c|c|c|c|c|c|c|}
\hline 10 & $\begin{array}{l}\text { SMOTE+(Bagging + } \\
\text { J48) }\end{array}$ & 0,801 & 0,248 & 0,790 & 0,801 & 0,778 & 0,796 & 0,777 \\
\hline 11 & $\begin{array}{l}\text { SMOTE+(Bagging + } \\
\text { Naïve Bayes) }\end{array}$ & 0,797 & 0,243 & 0,793 & 0,797 & 0,778 & 0,795 & 0,777 \\
\hline 12 & $\begin{array}{l}\text { SMOTE+(Bagging + } \\
\text { SMO) }\end{array}$ & 0,796 & 0,225 & 0,805 & 0,796 & 0,786 & 0,800 & 0,786 \\
\hline
\end{tabular}

Pada tabel 2 menunjukkan bahwa dengan penerapan metode resampling SMOTE (Synthetic Minority Over-sampling Technique) menghasilkan kinerja yang lebih baik dibandingkan dengan tanpa menggunakan metode resampling. Hal ini ditunjukan dengan adanya peningkatan accuracy pada semua model yang diuji. Hasil kinerja yang diperoleh menunjukan bahwa model pengklasifikasi SMOTE+Random Forest memiliki nilai accuracy yang lebih baik dengan beberapa model lainnya dengan nilai accuracy sebesar 0,808 atau $80,8 \%$ yang mengalami kenaikan 0,048 atau $4,8 \%$. Grafik perbandingan kinerja 12 model pengklasifikasi disajikan pada gambar 6 .

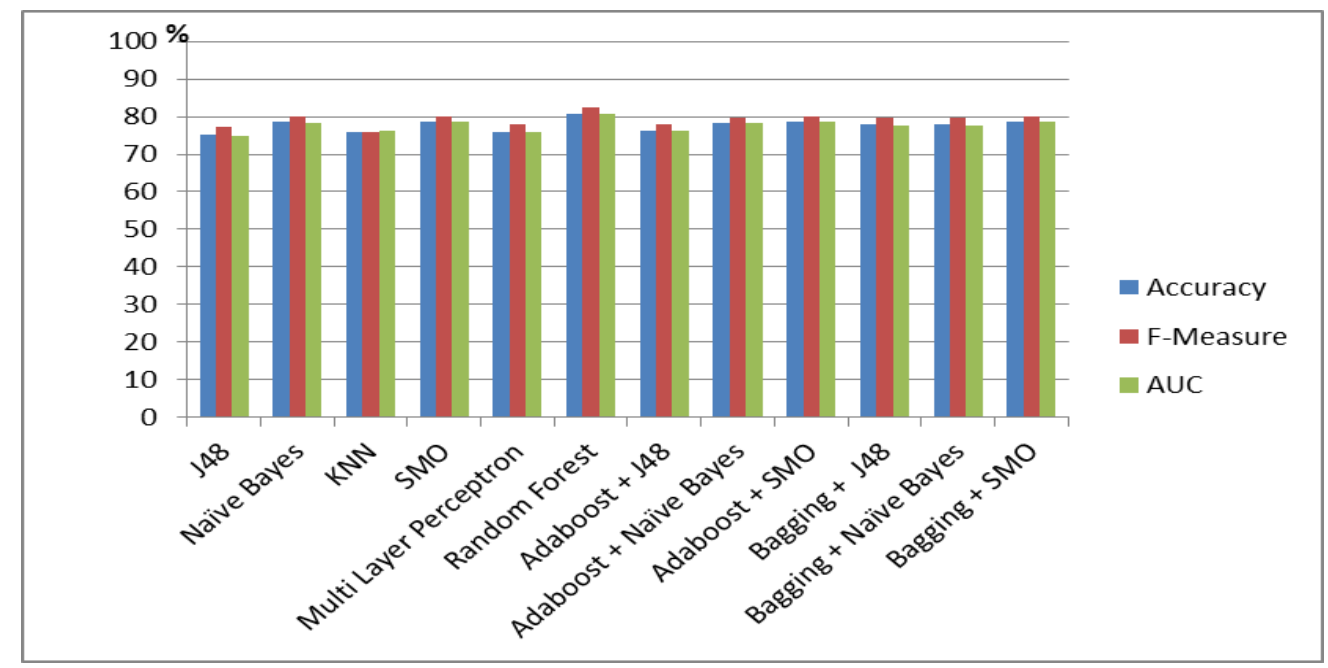

Gambar 6. Perbandingan kinerja Pemodelan dengan Metode SMOTE(Synthetic Minority Over-sampling Technique)

\subsection{Klasifikasi Random Over-Under}

\section{Sampling Random Forest}

Experimen dilakukan dengan menerapkan random over-under sampling pada metode random forest. Dimana data training menjadi seimbang antara class "good" dengan class "bad" dengan jumlah instance pada masing- masing class menjadi 500 instance. Hasil pengujian dibandingkan dengan 11 metode lainnya untuk menghasilkan model dengan kinerja akurasi terbaik. Hasil pengujian model pengklasifikasi dengan Random OverUnder Sampling disajikan pada tabel 3.

Tabel 3. Perbandingan kinerja model Pengklasifikasi dengan metode Random Over-Under Sampling (ROUS)

\begin{tabular}{|c|l|c|c|c|c|c|c|l|}
\hline No & \multicolumn{1}{|c|}{ Algoritma } & $\begin{array}{c}\text { TP- } \\
\text { Rate }\end{array}$ & $\begin{array}{c}\text { FP- } \\
\text { Rate }\end{array}$ & $\begin{array}{c}\text { Preci- } \\
\text { ssion }\end{array}$ & Recall & $\begin{array}{c}\text { Acu- } \\
\text { rracy }\end{array}$ & $\begin{array}{c}\text { F- } \\
\text { Measure }\end{array}$ & AUC \\
\hline 1 & ROUS+J48 & 0,824 & 0,148 & 0,848 & 0,824 & 0,838 & 0,836 & 0,838 \\
\hline 2 & ROUS+Naïve Bayes & 0,760 & 0,300 & 0,717 & 0,760 & 0,730 & 0,738 & 0,73 \\
\hline 3 & ROUS+KNN & 0,710 & 0,290 & 0,710 & 0,710 & 0,710 & 0,710 & 0,71 \\
\hline 4 & ROUS+SMO & 0,720 & 0,272 & 0,726 & 0,720 & 0,724 & 0,723 & 0,724 \\
\hline 5 & $\begin{array}{l}\text { ROUS+Multilayer } \\
\text { Perceptron }\end{array}$ & 0,830 & 0,100 & 0,893 & 0,836 & 0,868 & 0,864 & 0,865 \\
\hline
\end{tabular}




\begin{tabular}{|c|l|c|c|c|c|c|c|c|}
\hline 6 & ROUS+Random Forest & 0,864 & 0,062 & 0,933 & 0,864 & 0,901 & 0,897 & 0,901 \\
\hline 7 & ROUS+(Adaboost + J48) & 0,854 & 0,082 & 0,912 & 0,854 & 0,886 & 0,882 & 0,886 \\
\hline 8 & $\begin{array}{l}\text { ROUS+(Adaboost + } \\
\text { Naïve Bayes) }\end{array}$ & 0,740 & 0,310 & 0,705 & 0,740 & 0,715 & 0,722 & 0,715 \\
\hline 9 & $\begin{array}{l}\text { ROUS+(Adaboost + } \\
\text { SMO) }\end{array}$ & 0,710 & 0,276 & 0,720 & 0,710 & 0,717 & 0,715 & 0,717 \\
\hline 10 & ROUS+(Bagging + J48) & 0,780 & 0,166 & 0,825 & 0,780 & 0,807 & 0,802 & 0,807 \\
\hline 11 & $\begin{array}{l}\text { ROUS+(Bagging + Naïve } \\
\text { Bayes) }\end{array}$ & 0,772 & 0,296 & 0,723 & 0,772 & 0,738 & 0,747 & 0,738 \\
\hline 12 & ROUS+(Bagging + SMO) & 0,712 & 0,292 & 0,709 & 0,712 & 0,710 & 0,711 & 0,71 \\
\hline
\end{tabular}

Pada tabel 3 menunjukkan bahwa dengan penerapan metode Random Over-Under Sampling (ROUS) pada dataset sebelum dilakukan pemodelan dapat menghasilkan kinerja yang lebih baik dibandingkan dengan tanpa menggunakan metode resampling. Hasil kinerja yang diperoleh menunjukan bahwa model pengklasifikasi Random Over-
Under Sampling (ROUS)+Random Forest memiliki nilai akurasi yang lebih baik dibandingkan dengan beberapa model lainnya dengan nilai accuracy sebesar 0,901 atau $90,1 \%$ yang mengalami kenaikan 0,093 atau $9,3 \%$. Grafik perbandingan kinerja 12 model pengklasifikasi disajikan pada gambar 4

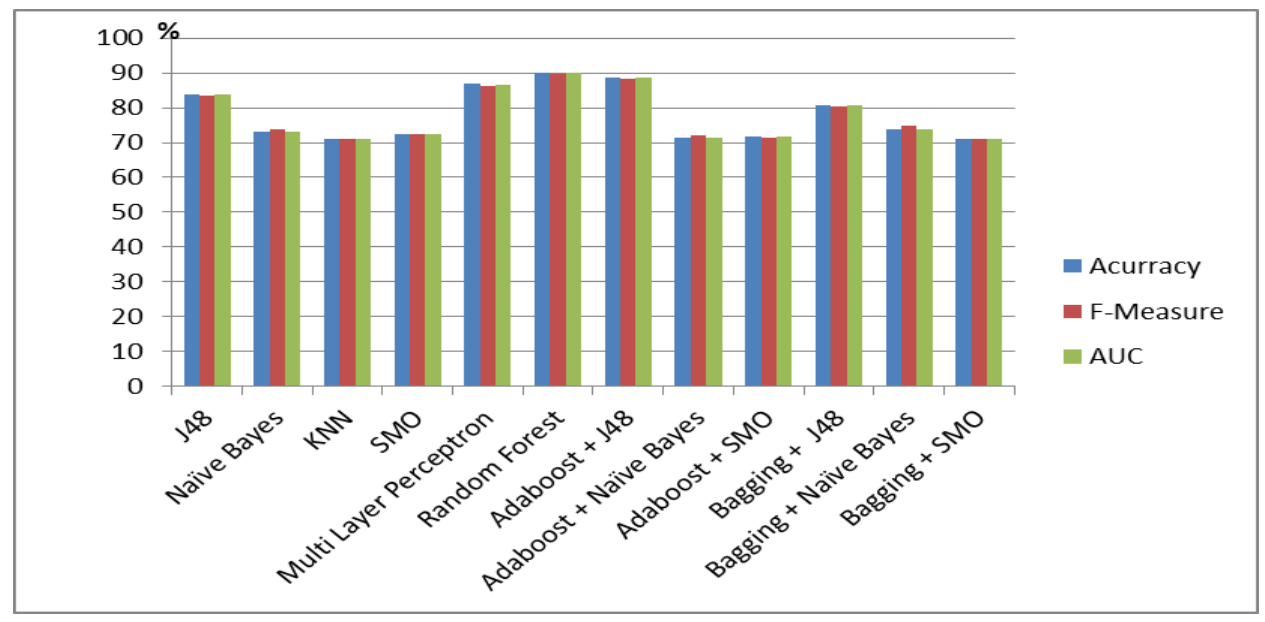

Gambar 4. Perbandingan kinerja Pemodelan dengan Metode Random Over-Under Sampling(ROUS)

\section{Kesimpulan}

Berdasarkan hasil experimen yang telah dilakukan pada dataset German Credit. Klasifikasi tanpa melalui proses resampling pada 12 pengklasifikasi menghasilkan kinerja akurasi rata-rata $70 \%$. Hasil klasifikasi menunjukan bahwa metode Random Forest memiliki nilai akurasi yang lebih baik dibandingkan dengan beberapa metode lainnya dengan nilai accuracy sebesar 0,76 atau $76 \%$. Sedangkan klasifikasi dengan penerapan metode SMOTE (Synthetic Minority Over-sampling Technique) pada algoritma Random Forest dapat meningkatkan kinerja akurasi sebesar 0,48\% dengan nilai akurasi 0,808 atau $80,8 \%$. Sedangkan klasifikasi dengan penerapan metode Random Over-under sampling+ Random Forest dapat meningkatkan kinerja akurasi sebesar $14,1 \%$ dengan nilai akurasi sebesar 0,901 atau 90,1 \%. Maka dapat disimpulkan bahwa penerapan resampling dengan metode Random Over-Under Sampling pada algoritma Random Forest dapat meningkatkan kinerja akurasi secara efektif pada klasifikasi tidak seimbang untuk penilaian kredit pada dataset German Credit. Namun untuk penelitian selanjutnya hal-hal berikut bisa ditambahkan untuk 
menghasilkan nilai akurasi yang lebih baik seperti berikut ini.

1. Pada penelitian selanjutnya dapat diterapkan teknik tingkat data lainnya seperti metode seleksi fitur (feature selection) untuk dapat meningkatkan akurasi pada klasifikasi penilaian kredit dengan ketidakseimbangan kelas.

2. Menggunakan dataset dengan jumlah instance yang lebih banyak, dan dengan rasio ketidakseimbangan kelas yang lebih tinggi.

3. Menerapkan metode ensemble learning lainnya dengan base classifier yang berbeda.

\section{Referensi}

Agrawal, K., Baweja, Y., Dwivedi, D., Saha, R., Prasad, P., Agrawal, S., ... Dutt, V. (2018). A Comparison of Class Imbalance Techniques for RealWorld Landslide Predictions. Proceedings - 2017 International Conference on Machine Learning and Data Science, MLDS 2017, 2018-Janua, 1-8. https://doi.org/10.1109/MLDS.2017.2 1

Dawson, C. W. (2009). Projects in Computing and Information Systems A Student's Guide (2nd ed.). Pearson Education Limited.

Han, J., Kamber, M., Pei, J., (2012). Data Minning Concept And Techniques. California: Morgan Kaufmann.

He, H., Zhang, W., \& Zhang, S. (2018). A novel ensemble method for credit scoring: Adaption of different imbalance ratios. Expert Systems with Applications, 98, 105-117. https://doi.org/10.1016/

j.eswa.2018.01.012

Jian, C., Gao, J., \& Ao, Y. (2016). A new sampling method for classifying imbalanced data based on support vector machine ensemble. Neurocomputing, 193, 115-122. https://doi.org/10.1016/j.neucom.201 6.02.006

Koutanaei, F. N., Sajedi, H., \& Khanbabaei, M. (2015). A hybrid data mining model of feature selection algorithms and ensemble learning classifiers for credit scoring. Journal of Retailing and Consumer Services, 27, 11-23. https://doi.org/10.1016/j.jretconser.20 15.07 .003

Lin, L., Wang, F., Xie, X., \& Zhong, S. (2017). Random forests-based extreme learning machine ensemble for multiregime time series prediction. Expert Systems with Applications, 83, 164176.

https://doi.org/10.1016/j.eswa.2017.0 4.013

Rajesh, K. N. V. P. S., \& Dhuli, R. (2018). Classification of imbalanced ECG beats using re-sampling techniques and AdaBoost ensemble classifier. Biomedical Signal Processing and Control, 41, 242-254. https://doi.org/ 10.1016/j.bspc.2017.12.004

Ren, F., Cao, P., Li, W., Zhao, D., \& Zaiane, O. (2017). Ensemble based adaptive over-sampling method for imbalanced data learning in computer aided detection of microaneurysm. Computerized Medical Imaging and Graphics, 55, 54-67. https://doi.org/ 10.1016/j.compmedimag.2016.07.01 1

Saifudin, A., Teknik, F., Pamulang, U., Komputer, F. I., Nuswantoro, U. D., \& Software, P. C. (2015). Pendekatan Level Data untuk Menangani Ketidakseimbangan Kelas pada Prediksi Cacat Software. Journal of Software Engineering, 1(2), 76-85.

Wang, G., Hao, J., Ma, J., \& Jiang, H. (2011). A comparative assessment of ensemble learning for credit scoring. Expert Systems with Applications, 38(1), 223-230. https://doi.org/10.1016/j.eswa.2010. 06.048

Xiao, J., Xie, L., He, C., \& Jiang, X. (2012). Dynamic classifier ensemble model for customer classification with imbalanced class distribution. Expert Systems with Applications, 39(3), 3668-3675.

https://doi.org/10.1016/j.eswa.2011.0 9.059 
Zhang, X., Yang, Y., \& Zhou, Z. (2018). A Novel Credit Scoring Model based on Optimized Random Forest. Computing and Communicating Workshop and Conference (CCWD), 2018 IEEE 8th Annual, 978(1), 6065. 